\title{
PEDOGEOMORPHOLOGICAL SYSTEMS IN THE INTERPRETATION OF THE EVOLUTION OF QUATERNARY LANDSCAPES IN HUMID TROPICAL CLIMATES
}

\author{
https://doi.org/10.4215/rm2019.e18020 \\ Felipe Gomes Rubira $a^{*}$ - André Mateus Barreiros ${ }^{b}$ - Fernando Nadal Junqueira Villela $c$ \\ Archimedes Perez Filho d
}

(a) Doctor in Geography. Professor Federal University of Oeste da Bahia, Barreiras (BA), Brazil.

ORCID: https://orcid.org/0000-0002-6594-8228. LATTES: http://lattes.cnpq.br/5268670455730660.

(b) Doctor in Geography. University of São Paulo, São Paulo (SP), Brazil.

ORCID: https://orcid.org/0000-0002-0691-8811. LATTES: http://lattes.cnpq.br/9221810181715372.

(c) Doctor in Geography. Professor University of São Paulo, São Paulo (SP), Brazil..

ORCID: https://orcid.org/0000-0002-7804-6565. LATTES: http://lattes.cnpq.br/7784362002921788.

(d) Doctor in Geography. Professor State University of Campinas, Campinas (SP), Brazil.

ORCID: https://orcid.org/0000-0001-6675-3740. LATTES: http://lattes.cnpq.br/4244941712717032.

Article history:

Received 1 June, 2019

Accepted 11 July, 2019

Published 15 September, 2019
(*) CORRESPONDING AUTHOR

Address: UFOB, Rua Bertioga, 892, CEP: 47810-059, Barreiras (BA), Brazil.

E-mail: felipe.rubira@ufob.edu.br

\section{Abstract}

There is always a relationship between soil and relief in the landscapes of humid tropical and subtropical climates, due to the thick mantles of regolith resulting from accelerated physical, chemical, and biological weathering. It is important to investigate pedogeomorphological systems in the systemic analyses of the origin and modeling processes of the terrestrial surface. This paper seeks to establish the central relationships between Geomorphology and Pedology, and the importance of pedogeomorphological systems in the evolutionary interpretation of quaternary landscapes in humid tropical climates. Thus, the discussions address the influence of landforms on soil formation and spatialization and the pedological impacts on the modification of relief forms, as well as the methodological support from Pedology to Geomorphology concerning the evolutionary interpretation of tropical landscapes. Therefore, there is evidence of the need for closer links between the studies of geomorphological and pedological systems in the analysis of tropical landscapes.

Keywords: Geomorphology, Pedology, Morphogenesis, Pedogenesis, Structural Analysis of Pedological Cover.

\section{Resumo / Resumen}

SISTEMAS PEDOGEOMORFOLÓGICOS NA INTERPRETAÇÃO DA EVOLUÇÃo DE PAISAGENS QUATERNÁRIAS EM CLIMAS TROPICAIS ÚMIDOS

As relações entre solo e relevo são constantes em paisagens de climas tropicais e subtropicais úmidos, devido aos espessos mantos regolíticos resultantes de acelerado intemperismo físico, químico e biológico. A investigação dos sistemas pedogeomorfológicos merece destaque em análises sistêmicas, que objetivam o estudo da gênese e dos processos modeladores da superfície terrestre. Este artigo objetiva estabelecer as principais relações entre a Geomorfologia e Pedologia, e a importância dos sistemas pedogeomorfológicos para a interpretação evolutiva de paisagens quaternárias em climas tropicais úmidos. Deste modo, são realizadas discussões sobre as influências do relevo na formação e espacialização dos solos, influências pedológicas na modificação das formas de relevo e subsídios metodológicos da Pedologia para a Geomorfologia em relação à interpretação evolutiva das paisagens tropicais. Evidencia-se, portanto, a necessidade de aproximação entre os estudos de sistemas geomorfológicos e pedológicos na interpretação das paisagens tropicais.

Palavras-chave: Geomorfologia, Pedologia, Morfogênese, Pedogênese, Análise Estrutural da Cobertura Pedológica.

SISTEMAS PEDOGEOMORFOLÓGICOS EN LA INTERPRETACIÓN DE LA EVOLUCIÓN DE PAISAJES CUATERNARIAS EN CLIMAS TROPICALES HÚMEDOS

Las relaciones entre el suelo y el relieve son constantes en paisajes de climas húmedos tropicales y subtropicales, debido a los gruesos mantos regolíticos resultantes de la meteorización física, química y biológica acelerada. La investigación de los sistemas pedogeomorfológicos merece atención en los análisis sistémicos, cuyo objetivo es estudiar la génesis y los procesos de modelado de la superficie terrestre. Este artículo tiene como objetivo establecer las principales relaciones entre la geomorfología y la pedología, y la importancia de los sistemas pedogeomorfológicos para la interpretación evolutiva de los paisajes cuaternarias en climas tropicales húmedos. Por lo tanto, se mantienen debates sobre la influencia del relieve en la formación y la espacialización del suelo, las influencias pedológicas en la modificación de las formas de relieve y el apoyo metodológico de la pedología a la geomorfología en relación con la interpretación evolutiva de los paisajes tropicales. Por lo tanto, la necesidad de aproximación entre los estudios de sistemas geomorfológicos y pedológicos en la interpretación de paisajes tropicales es evidente.

Palabras-clave: Geomorfología, Pedología, Morfogénesis, Pedogénesis, Análisis Estructural de la Cobertura Pedológica 


\section{INTRODUCTION}

In his conceptual review, Queiroz Neto (2011) highlights the relationship between the interdependent sciences of Pedology and Geomorphology, whose importance is verified by scientific works such as those of Milne (1935 and 1936), Jenny (1941), Tricart (1968) and Boulet (1982a; 1982b; 1982c). For Tricart (1968), this proximity is due to the alteration of the rocks, a process in which pedogenesis contributes to morphogenesis. The latter predominates on steep slopes, while pedogenesis occurs on gentle slopes with a deeper pedological cover. From this, Tricart (1968) demonstrates the interdependence between morphogenesis, pedogenesis and the action of water flows in various ways, establishing that slope dynamics are an excellent instrument to understand the origin of soils.

However, the pedogeomorphological relationships currently observed in scientific research have not always been made explicit. Studies of these associations are fragmented, without any systemic, multidisciplinary research to demonstrate the interdependence between the two disciplines. Also, they were not capable of revealing the influences of relief on soil formation and spatialization, or the influences of pedogenesis on morphological alterations and the relief forms arrangement.

From this theoretical approach, this article aims to establish the central relationships between Geomorphology and Pedology. The general intention is to highlight the importance of pedogeomorphological systems in the evolutionary interpretation of quaternary landscapes in humid tropical climates, to lessen the historical dichotomy that persists between the two sciences.

Therefore, the deliberations center on the relief's influence on soil formation and spatialization, and the pedological influences on the alteration of landforms. They also address Pedology's methodological support of Geomorphology, in terms of the evolutionary interpretation of tropical landscapes.

\section{METHODOLOGY}

The analysis highlights the relief's influence on soil formation and spatialization, addressing the following relationships: slope (terrain declivity) and soil type; slope and soil erosion; slope and the distribution of water flows; slope and soil organic matter; slope and soil textural classes; slope and soil fertility; and, slope and land use.

The pedological influences on the modification of landforms are also established, including the relationship of water / geochemical actions in soils modifying the slope form; the association of soil laterization processes and the influences on landscape morphogenesis; and the relationship of mass movements with the creation of new forms of relief.

Finally, theoretical discussions are promoted that clarify methodological supports rendered by Pedology and Geomorphology regarding the evolutionary interpretation of tropical landscape, evidencing the concepts of biostasy, resistance, surface formations, and pedological cover. In this context, there is a brief discussion about Structural Analysis of Pedological Cover methodology, which is gaining ground in the integrated, systemic study of soils and landforms, with varied approaches and a multiscale scope. This section examines the results achieved by this method after more than 30 years of research in the tropics.

\section{INFLUENCE OF THE RELIEF ON SOIL FORMATION AND SPATIALIZATION}

Before moving on to the main discussion, it is pertinent to emphasize the wide-ranging impact of the influence of pedogenesis and morphogenesis due to the vast scale of these phenomena. Geomorphological interference in pedogenesis affects large spatial cutouts, equivalent to Ross's second and third taxa (1992). For example, the steep slopes in scarp areas control all pedogenesis, distribution, and spatialization of soils on the edge of plateaus, pediment zones, and adjacent colluviums. Meanwhile, pedological influences also interfere with morphogenesis and the modification of landforms. However, this takes place in smaller spatial cutouts corresponding to the fourth and fifth taxa (ROSS, 1992), 
associated with the smaller relief forms such as hills, ridges, and slopes.

The first example in this context is declivity's influence on the formation of particular soil types and their respective spatial distribution, a factor that has been highlighted in pedogeomorphological research (OLIVEIRA et al., 1992; LACERDA et al., 2005; RESENDE et al., 2005; SOUZA JUNIOR and DEMATTE, 2008). These authors emphasize the relevance of knowledge regarding soil distribution in the relief for pedological surveys; it is a probable indicator of the occurrence of a particular soil type. However, it is worth noting that despite considering it an indicator of probable occurrence, Embrapa (1999) does not limit a specific soil layer to declivity. These studies show that the variation of soils on different slopes is driven by the differentiated distribution of rainwater percolation by gravitational action.

Thus, Souza Junior and Demattê (2008) and Queiroz Neto (2010 and 2011), correlate flat reliefs with higher rates of water infiltration (subsurface flow) to the detriment of surface runoff, which are responsible for intensifying the performance of the deep geochemical processes of hydrolysis and dissolution and enhancing chemical weathering. Such dynamics favor the formation of thick nutrient-poor regolith layers, with a low Cation Exchange Capacity (CEC) and base saturation (V\%), and a predominance of oxides.

On the other hand, the authors associate steep slopes with a stronger action of surface runoffs to the detriment of infiltration amount. In this dynamics, the pedological covers are subjected to constant abrasion by intensified linear erosive processes, which limit the actions of hydrolysis and dissolution. These phenomena caused by scarped reliefs promote ongoing soil rejuvenation, resulting in nutrient-rich shallow soils and primary minerals, with a high CEC and V\%.

Under this perspective, the research by Bennema et al. (1962) may be remarked. They observed that the rugged mountainous areas of South America were covered in Lithosols (Litholic Neossols and Regolithic Neossols), with poorly developed pedological formations, whereas, medium-developed Red Yellow Argisols predominated in hilly (dissected) reliefs. Plateau regions were mainly covered by Latosols, which are thicker, well-developed soils from the pedogenetic point of view. These pedogeomorphological correlations were the foundation of convergent evolutionary interpretations about the age of South American landforms and soils, based on Davisian concepts and the relief's life cycle. However, nowadays, there is evidence that the use of this terminology is no longer tenable.

Similarly, more recent researchers such as Lacerda et al. (2005), Resende et al. (2005) and Souza Junior and Demattê (2008) point to the occurrence of shallower and less-evolved Cambisols and Litholic Neossols on steep slopes and deeper and more evolved Latosols and Argisols on flat and undulating slopes, closer to the inferences of Bennema et al. (1962).

The relationship of declivity with soil erosion potential is emphasized by Grossman (1983), Hall and Olson (1991), Souza et al. (2003), Chagas et al. (2013) and Rubira et al. (2016), who believe that the erosive process in pedological formations arranged on steep gradients is accentuated, because morphogenic action is imposed on the speed of pedogenetic actions, causing a reworking of the materials. On the other hand, the authors argue that in level landforms pedogenetic actions predominate in the landscape to the detriment of the less efficient morphogenetic processes.

For Galeti (1982), Bertoni and Lombardi Neto (1985) and Bastos (1999), erosion is directly proportional to declivity and slope length, influencing water velocity. As these factors increase, the runoff path and velocity also intensify, enhancing the power to detachand transport soil particles. In this interim, the flow of water runoff depends on the surface morphology, whose horizontal and vertical features (as seen in plant and profile views) act to disperse the surface and subsurface flows (TROEH, 1965).

Morphology and hydrodynamics are essential elements in the relationship between landforms and the distribution of water flows. When considering the action of gravity and the geometric aspects and topographic gradients of slopes (RUHE, 1975), their shape, indicated by their contours (profile view) and radials (plan view), influence the surface and subsurface flows. Convexities and concavities are factors that shape the dispersion patterns and drainage concentration, while rectilinear forms induce neutral hydric flows that neither disperse nor concentrate water (TROEH, 1965; YOUNG, 1972; RUHE, 1975; COLANGELO, 1996; ARANHA, 2011).

The relationship between the relief and the distribution of organic matter along the slopes was 
observed in research developed by Curi and Franzmeier (1984), Lepsch and Buol (1986) and Cunha et al. (2005).

In addition to these authors, Silva and Torrado (1999) and Silva et al. (2007) carried out studies using the relationships between declivity and landscape evolution as a starting point to understand the genesis of the Humic Latosols of southern Minas Gerais. To this end, points were selected in different slope segments (shoulder, half slope, and foot) and a quantitative assessment was made of the slope and the degree of humification of the organic matter. They concluded that the accumulation of organic matter and the degree of humification are closely correlated with the relief; the gentler the slope, the higher the accumulation rate and degree of humification.

The relationships between the relief and soil textural classes were studied by Santos et al. (2002), and Santos (2004), based on results from tests carried out in watersheds in the State of Paraíba.

Santos et al. (2002) collected 300 soil samples at $0-20 \mathrm{~cm}$ depth in different segments of the Vaca Brava stream basin (floodplain, top, pediment, and slope). The results showed the relief's influence on the sediment distribution and soil texture along the slopes analyzed. Fine-grained soils predominated higher up and, conversely, coarser textures prevailed on the lower slopes, due to the higher sand content. Thus, the authors established associations between the slope compartments and the distribution of thinner textures on the slopes, in contrast to the areas of pediment and floodplains where thicker consistencies resulted from the redistribution of sediments by erosion.

Cunha et al. (2005) reported similar findings when investigating the correlations between geomorphic surfaces and the attributes of Latosols in topolitho-sequences performed in Jaboticabal (SP). The authors demonstrated how topographic factors control the variations in texture, as there was a steady, gradual increase in particle size from the top to the foot of the slope.

Recent research has aimed to relate soil fertility with slope declivity. Galvão et al. (2005) and Santos et al. (2008) examined the combination of soil fertility in five slope positions, to ascertain the influence of morphology on $\mathrm{Ca}, \mathrm{Mg}, \mathrm{K}, \mathrm{P}, \mathrm{Na}, \mathrm{H}+\mathrm{Al}$ and delta $\mathrm{pH}$ levels. In different slope positions (shoulder, half slope, linear slope, pediment, and floodplain) $\mathrm{Ca}, \mathrm{K}, \mathrm{pH}$, and $\mathrm{H}+\mathrm{Al}$ contents remained relatively uniform. The $\mathrm{P}, \mathrm{Mg}$ and $\mathrm{Na}$ levels were higher in floodplain areas than on the slope (shoulder, half slope, linear slope, and pediment), due to the interference of farmers who cultivated these soils more intensively.

The research results outlined above were unexpected. However, they were still important because they brought a new, under-explored theme to the debate on pedogeomorphological systems.

In contrast, Leão's (2004) evaluation of the relationship between the attributes of a slope with Latosols and the quality of citrus fruits, found that variations in morphology can influence the spatial behavior of soil fertility and the quality of the harvest. Similarly, Souza et al. (2004) investigated the spatial variability of the physical attributes of soils in different landforms under sugarcane cultivation and concluded that the position in the relief interfered with the spatial distribution of these characteristics, which are partly responsible for soil fertility.

Based on the above, more quantitative research is required to examine this relationship in new locations so that all the results can be compared. Additional analyses will either strengthen the hypothesis of the non-dependence between soil fertility and relief (GALVÃO et al., 2005; SANTOS et al., 2008) or confirm that this dependence exists, as demonstrated by the findings of Leão (2004) and Souza et al. (2004).

Lepsch et al. (1991), Santos et al. (2002and 2008) and Chagas et al. (2013) investigated the relationship between declivity and land use and ascertained that the classification and interpretation of river basin relief are vital to the planning and application of sustainable, productive management.

Regarding the variations in the particle size in different slope segments, Santos et al. indicate that in general, areas with steep slopes and thin soils are used for pasture, whilst annual crops are cultivated on low slopes with thick soils, due to the higher water infiltration rates and the ease of preparation. Along the same lines, Santos et al. (2008) indicate that the redistribution of water and sediment caused by the relief determine the selection of arable land by farmers. Therefore, from these studies, it is clear that landforms have a direct and indirect influence on decisions regarding land use.

The pedogeomorphological correlations highlighted above and the work of Gallant and Wilson 
(2000) evidence that declivity is the most critical geomorphological factor controlling pedogenetic processes, where landforms demonstrate the mechanisms that help to interpret the evolution of pedogenetic processes.

These ideas are summarized in Figure 1, highlighting the influence of declivity on the formation and spatial distribution of soils and some soil-related processes that are affected by slopes (Figure 1). Finally, it indicates that more natural and social elements are interacting systemically with soils and the relief and that this set of relationships establishes the structure and functioning of landscapes, which change in time and space as they are modified.

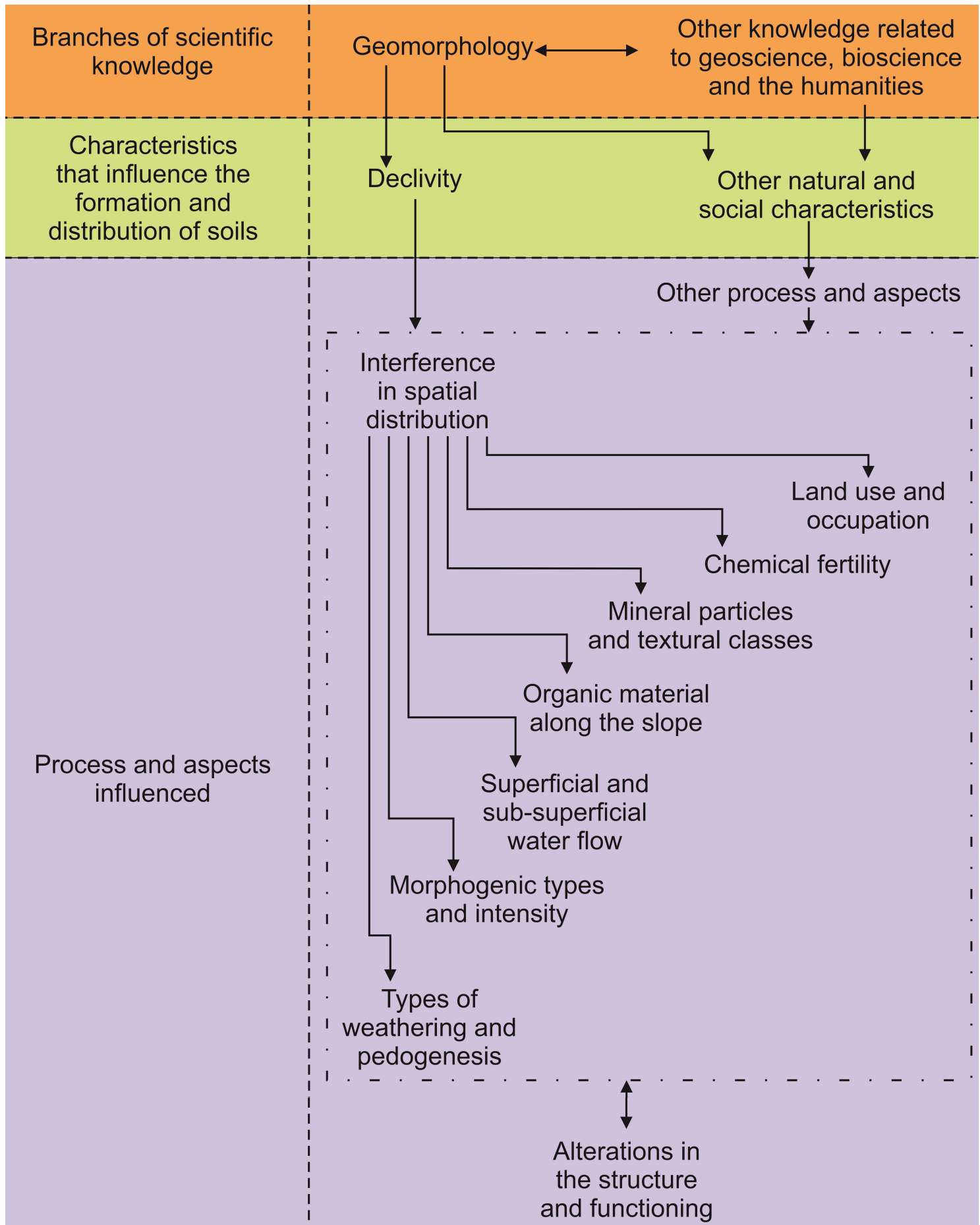

Figure 1 - Synthesis of the influence of relief on soil formation and spatialization. 


\section{PEDOLOGICAL INFLUENCES IN THE MODIFICATION OF LANDFORMS}

As discussed in the previous section, the morphographic and morphometric characteristics of landforms profoundly influence the formation and distribution of soils. However, some significant pedogenetic processes can alter this morphology.

Queiroz Neto (2011) states that the internal action of water exerts a direct influence on the formation of soils and relief modeling, as the movement of water acts on the migration of elements, a phenomenon evidenced in the leaching process.

In the same vein, Tricart (1968) shows the interdependence between morphogenesis, pedogenesis, and the action of subsurface water flows. Some infiltrated water is taken up by the roots and replaced in the atmosphere by plant transpiration before it can travel deeper. This process suspends certain materials that are subsequently abandoned in the upper horizons in the form of plant debris.

According to the author, another percentage of the water escapes the evapotranspiration process and continues underground acting as a leaching agent that interferes with pedogenesis. Finally, the remaining infiltrated water feeds the hypodermic flow; this is more frequent in humid tropical environments.

Based on these correlations, there are a number of significant studies that associate the influence of pedogenetic processes driven by the action of subsurface water flows on slopes, such as: Fernandes Barros (1985) and Castro (1990) in studies of the Paulista Western Plateau, in the city of Marília (SP); Dias Ferreira (1997) in research on Piramboia sandstone in the region of São Pedro (SP); Lucas et al. (1984) in the municipality of Manaus (AM); and Rubira et al. (2017) at the Experimental Farm of the State University of Maringá (UEM), in Iguatemi (PR).

This research evaluated evolutionary slope dynamics from the E and Bt Argisol horizons, where the action of subsurface water flows causes an upward trend. The authors observed the transformation of the latosolic horizon $(\mathrm{Bw})$, located in the upper and middle slope, into clay $(\mathrm{Bt})$, which begins at the slope base and advances to the top. In the case of these studies, this dynamics modifies convex slopes, forming the concavities that promote sandy steps in the relief modeling.

According to Fernandes Barros (1985) and Rubira et al. (2017), the intensification of this process accumulates more water and increases the loss of clay, deepening the foot of the slopes, effectively making them concave. For these authors, the triggering of these processes is probably related to changes to the local base level of nearby rivers, which may accelerate the internal flows of the solutions in the slope through geochemical activities that, at the same time, sculpt new landforms, forming concave profiles.

According to Penteado (1978), it is essential to study the soil-relief relationship because it may indicate the denudation speed in relation to the weathering velocity. Therefore, researching the morphogenetic balance of slopes gives insights into paleoclimatic actions, which are essential for geochronological interpretations of the evolution of humid tropical quaternary landscapes and paleomorphogenetic reconstitutions, since identifying paleosols might indicate the resumption of erosion. In this context, the author highlights the relationship of laterization processes in tropical landscapes and their influences on the landscape's morphogenetic configuration.

The present article has adopted the terminology of laterization as it involves several processes in tropical humid environments that are associated with intense chemical weathering. Due to geochemical processes, the concentration of iron and aluminum oxides gives rise to a residual product that quickly dehydrates and hardens when exposed to the air. It is worth mentioning some terminology used in scientific research that may refer to the same thing: ferralitic alteration, ferruginous hardening, relative accumulation of iron, absolute accumulation of iron, lateritic duricrust, laterite, lateritic carapaces, ferruginous carapaces, ferruginous concretions, duricrust and shale (TRICART, 1956; AB'SÁBER, 1957; PENTEADO, 1978; ESPÍNDOLA, 2010; ALVES et al., 2014).

The laterization processes responsible for forming the duricrust are typical of tropical climates, where leaching and chemical weathering are intense during the rainy seasons, while iron and aluminum oxides and hydroxides accumulate in the dry seasons. Thus, the minerals are attacked, the silica is dissolved, and the concentration of iron and aluminum oxides is intensified. As a result, the soil 
dehydrates, and forms hardened crusts that alter the landscape's morphogenetic processes and the morphological configuration of landforms.

Three important studies in this field were carried out by Tricart (1956), who investigated duricrusts in Africa, Ab'Sáber (1957), who analyzed lateritic deposits in the crystalline plateaus of Goiás, and Penteado (1978), who identified allochthonous breastplates in tropical forests. They associated the origin of this phenomenon with three episodes of morphoclimatic alternations. The first involves a humid tropical climate responsible for producing the clayey A-horizon and the concretionary B-horizon. The second is a more aggressive, dry climate, which intensifies the morphogenetic processes responsible for eliminating the superficial A-horizon, dehydrating and hardening the diagnostic B-horizon, turning it into a crust. The third is a semi-arid climate responsible for the denudation of the surface, accentuating the morphogenetic processes that erode part of the duricrust and transport materials to other locations, which are later cemented by ferruginous solutions in new climatic alternations.

This theoretical and methodological morphoclimatic framework evidences the importance of these geomorphic surfaces in the reconstitution of tropical quaternary landscapes, representing interpretative records of the paleoprocesses that developed during successive climates.

At the same time, the literature shows how laterization processes alter the surface topographic morphology through the thickness of the duricrust, which can reach several meters; its chemistry hinders the immobilization of residues. Its physical composition, with extremely compact textures and rare fissures, hinder water infiltration and percolation.

These discussions verify the influence that the duricrust can have on landforms. Based on the work of Penteado (1978), a number of notable topographical changes can be highlighted: the conservation of old erosion surfaces; greater resistance to erosive processes due to the concretionary material; increased differential erosion compared to softer nearby rocks, changing the topography; inversions in the relief caused by the erosion-wear-resistant duricrust that protrudes from the landscapes, while adjacent elevations with more friable rocks may be worn and lowered; surface runoff favored over infiltration; and, the formation of landscapes with flattened surfaces and the demarcation of palaeosol levels.

Another notable pedogeomorphological relationship is the alteration of landforms due to mass movements of the regolith. Research into the modifications in alluvial geomorphological compartments due to landslides is still rare. In general, the main investigations of mass movements revolve around: applying mathematical models to predict landslides; the delimitation of critical / susceptible risk areas where this process may occur; the safety factor of slope stability; the correlation of mass movements with damage to municipalities and the subsequent social, political and economic consequences.

In this context, Almeida and Carneiro (1998) and Silveira et al. (2012) focus attention on some remarkable changes in valley bottoms in their studies of the floodplains adjacent to high slopes and high mountain ranges, which are more susceptible to landslides.

According to the authors, landslides completely alter alluvial plains leaving them full of debris consisting of blocks and rock fragments of varying sizes, and loose sandy and clay sediments, as well as plant debris from tree trunks, branches, roots, and leaves. Also, the deposits spread out in the valleys are remobilized.

River plains are morphologically altered by the debris, leading to the aggradation of riverbeds and possible alluvial avulsions. Coarse materials give rise to detritus cones at channel outlets, while fine sediments are scattered over large stretches of floodplains, which spread after torrential precipitation and the resulting river flows. Such phenomena directly interfere with the organization and spatialization of river terraces; depending on the event's magnitude they can be covered and disappear.

The alluvial geomorphological compartments are the most affected, unlike the rock massifs in mountainous areas, which are more resistant to landslides due to their petrography and structure and thus retain their height.

For Almeida and Carneiro (1998) these processes are part of the natural evolution of landforms in these environments, which are capable of modifying the role of morphogenesis and pedogenesis, as well as the floodplains' pedogeomorphological systems. 
As above, these ideas are summarized in Figure 2. It is suggested that pedogenesis influences the modification of landforms since it alters processes such as water flow, morphogenesis, and the evolution of landscapes. The findings are similar: more natural and social elements are interacting systemically with soils and reliefs. This complex of relationships is responsible for the organization and dynamics of landscapes (Figure 2).

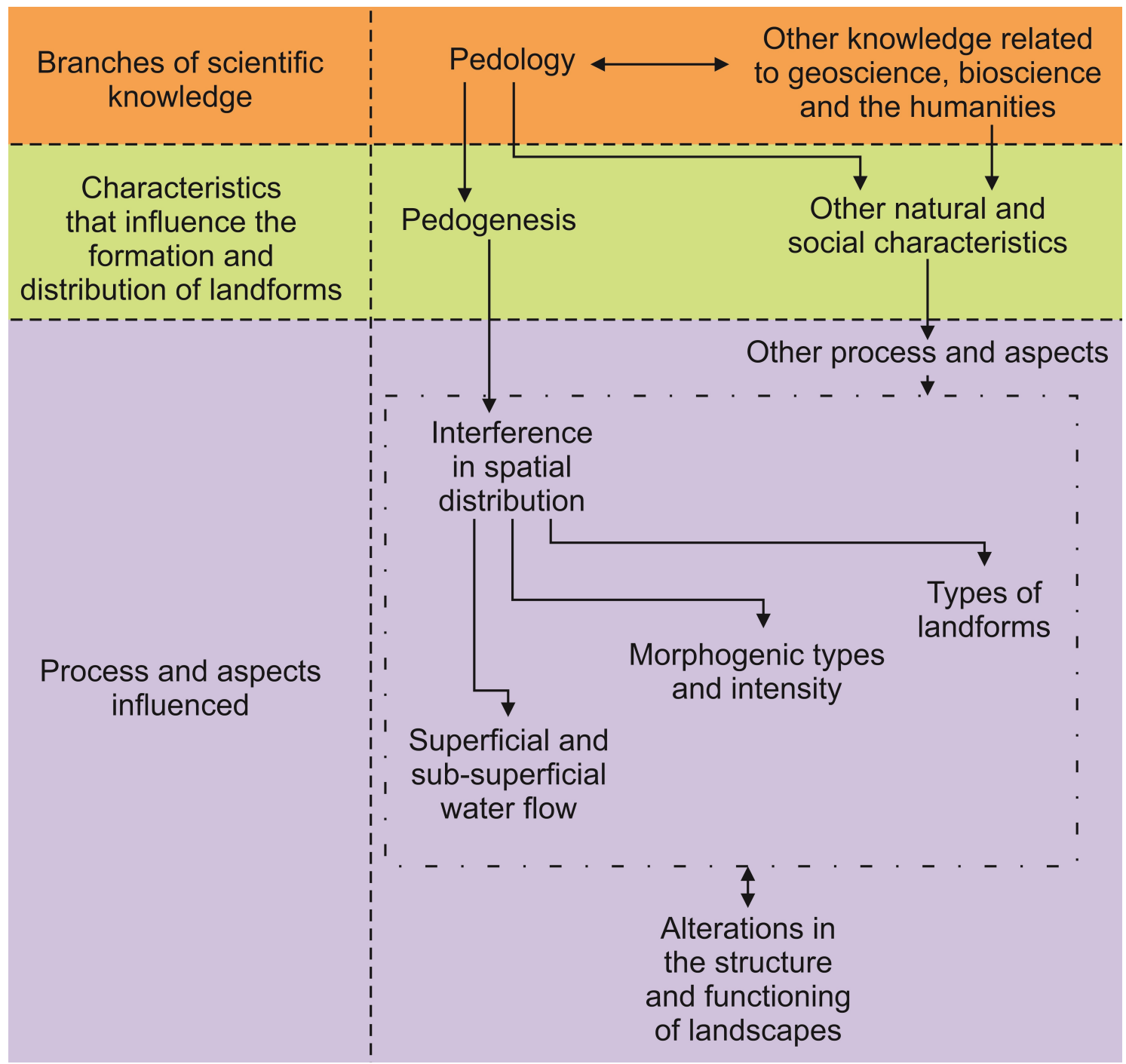

Figure 2 : Synthesis of pedological influences in the modification of relief forms. Source: Compiled by the authors

\section{THE METHODOLOGICAL CONTRIBUTION OF PEDOLOGY FOR GEOMORPHOLOGY IN TERMS OF THE EVOLUTIONARY INTERPRETATION OF TROPICAL LANDSCAPES}

As pointed out, the interface between the geomorphological and pedological sciences indicates that there is no conflict between morphogenesis and pedogenesis. The complementarity between the dynamics and genesis of the soil and relief is part of the same framework of physical, chemical, and biological processes that occur in the lithosphere's interaction with the atmosphere. Thus, the parallelism and / or synchronism of soil and relief evolution in a given area is not necessarily continuous; if there was alternation, they could not coincide in time and space (COLANGELO, 2007). 
One evolutionary theory with a strong duality regarding the interaction between morphogenesis and pedogenesis is the biorhexistasys proposed by the French researcher Erhart (1956), who states that the landscape's evolution is a product of the symbiotic and functional relationship of phases over geological time. These phases are primarily affected by the presence or absence of vegetation influenced by morphogenesis and pedogenesis. In the biostatic phase, when an exuberant vegetation cover predominates, the climate is humid, and soil formation is mainly due to chemical weathering. In periods of rhexistasy, the dry climate and low vegetation density favor the mechanical actions of erosion, intensified by torrential, sporadic rainfall. Thus, deforested surfaces are in a state of rhexistasy and are gradually depleted by erosive processes that tend to intensify, until a biostatic phase assumes as a resumption of equilibrium for the environmental conditions.

In the mid-twentieth century, the dual nature of this morphogenetic balance seems to have been circumvented by other French scholars, who established the associations between pedogenesis and geomorphology through surveys of surface formations (JOURNAUX, 1973; DEWOLF, 1983; QUEIROZ NETO, 2001). These landforms are materials that cover the upper part of the crust, arising from changes to the rocks by physical, chemical and biological weathering, and may have been relocated and / or reworked over slopes, erosion surfaces and flood plains (DEWOLF, 1983). They are evidence of the pedogenetic and morphogenetic processes that determine the evolution and dynamics of the earth's surface (QUEIROZ NETO, 2001).

The study of superficial formations reveals that the unconsolidated materials covering the surface are residual deposits, signs of long periods of erosion in the formation of a generalized surface, both as correlative deposits and the product of tectonic uplift. Journaux (1973) indicates that for Geomorphology these studies allow inferences to be drawn about landforms' origins, the relative chronological dating of deposits and the (paleo) climatic conditions that persisted during the accumulation of unconsolidated materials.

In Brazil, Pedological and Geomorphological research highlighted the evolution of landforms by defining the autochthonous and allochthonous nature of materials (FEUER, 1956; BIGARELLA et al., 1961; AB'SÁBER, 1962; BENNEMA et al. 1962; BIGARELLA et al., 1965; CARVALHO et al., 1969; QUEIROZ NETO, 1969; COUTARD et al., 1978; DIAS FERREIRA et al., 1978). Some criteria were employed to define allochthony and autochthony through a study of superficial formations, such as the presence of stone-lines with or without ferruginous concretions, which would differ from the geological substrate and follow the slope profile, as well as the marked differences in the mineralogical composition or chemical properties of successive horizons, and the presence of buried horizons rich in organic matter and evidencing the presence of paleosols (QUEIROZ NETO, 2001).

However, since the 1970s, Structural Analysis of Pedological Coverage has offered new perspectives in the definition of autochthonous and allochthonous materials, in addition to evaluating the importance of bio-geodynamic processes in the elaboration of relief forms, alongside the dissemination of the climatic-genetic geomorphology developed by Büdel (1982), or Millot's (1977 and 1983) work on the influence of soil development on slopes. Research by Delvigne (1965), Bocquier (1973), Chauvel (1977) and Boulet (1978), among others, laid the foundations for this analysis, detailing the relationships between the vertical and lateral distribution of soils in the landscape along the slope, especially on a local scale. They demonstrate that soils cover the terrestrial surface almost continuously, in an intimate relationship with landforms.

This multiscalar methodology investigates the interaction of different elements, including rocks, climate, vegetation and human activity in the formation and evolution of the materials and landforms found on the earth's surface, and their relationships with weathering, pedogenic and morphogenetic processes (BOULET et al., 1982a; 1982b; 1982c; BOULET, 1988; RUELLAN and DOSSO, 1993). In general, Structural Analysis aims to synthesize the landscape's structure and dynamics on a local and regional scale, and the implications for the genesis and evolution of the pedological cover and the relief.

Accordingly, this methodology unifies the generalist suggestions of Dokuchaev's (1967) Pedogenetic Zonality Law with the procedure indicated by Milne's (1935 and 1936) study in catenas. It is a hybrid approach and a new form of analysis of environmental changes and the interactions between soils and landforms. In other words, Structural Analysis is a methodology, that is, a set of methods, techniques, and procedures originating in Pedology that has become transversal to knowledge related to 
those geosciences that study landscape organization and dynamics (NAKASHIMA et al., 2017).

The spread and application of this empirical and experimental analysis to different tropical locations has given rise to some general conclusions about the relations of pedological cover with relief modeling and landscape evolution (BOULET et al., 1982a; BOULET et al., 1984; PELLERIN and HELLUIN, 1988; RUELLAN, 1988; BOULET, 1992; QUEIROZ NETO, 2001, 2002 and 2011; ESPÍNDOLA, 2010). These conclusions can be summarized as follows:

The pedological cover is a dynamic natural body, with transfers and transformations of matter and energy within it;

It has a multiscale organization, where forms, materials, and processes are more complexly related, from a planetary to a local scale;

The intrinsic dynamics of the elements in the cover enable pedological self-evolution, where an initial cover gives rise to another with completely different characteristics, due to transformation systems;

The physical, chemical and mineralogical transformations that occur in the pedological cover modify its structural organization and volume, implying changes in the relief, that is, the surface changes through the combined action of weathering, pedogenic and morphogenetic processes;

The alteration in the water circulation in slopes is the starting point for changes in the pedological cover and landforms, as it is responsible for several forms of remobilization of matter throughout the landscape;

The circulation of water is altered by tectonic, climatic or anthropogenic modifications in the hydrographic network's base level, implying a modification from the state of dynamic equilibrium to a pedobioclimatic imbalance and the emergence of a new cover and new terrestrial configurations.

Further to the results of Structural Analysis, possibly the greatest progress in the association between Pedology and Geomorphology resulted from the physical, chemical and biological knowledge acquired regarding the relationship of pedogenetic processes with landform evolution. Eventually, the classification of surface materials as surface formations was no longer feasible, as they were perceived as in situ pedogenetic variations, implying volumetric alterations from the transformation, migration, precipitation, and arrangement of materials.

Studies conducted in the humid tropics in Africa, the Brazilian Amazon, or the Paraíba Valley, Southeast Brazil support this finding. The geochemical alteration of the rock minerals and the consequent transformation of primary minerals to secondary ones leads to a loss in the mass of the original rock, which becomes saprolitic. However, as the saprolite's alteration by biogeochemical mechanisms advances, it turns into a soil that develops a profile organized into horizons. This process reduces the volume of the pedogenized and altered material, where the collapse of the iron-clay bonds, in addition to the leaching of $\mathrm{Fe}$ and $\mathrm{Al}$ oxyhydroxides, leaves behind the thicker residual fraction $(\approx$ quartz), resulting in landscape planing due to pedogenesis and the formation of horizons. Moreover, the effects of these processes are often visible in the landscape by the inflections or changes in declivity (MILLOT, 1977 and 1983; BOULET et al., 1984; CHAUVEL and LUCAS, 1992; THOMAS, 1994; COLTRINARI, 2003 and 2011).

It is worth highlighting that in the Brazilian humid tropics, pedogenetic processes and relief evolution do not necessarily happen along the lines mentioned by the authors above. Variations in morphogenetic systems and morphoclimatic domains invariably change the mechanisms that occur under the climatic influences of different regions (TRICART, 1965; TRICART and CAILLEUX, 1972). An example of this is the Paulista Peripheral Depression, whose landform downgrading is attributed to geochemical processes that do not have evolution entirely similar to the mentioned works as can be seen in researches like Furquim (2002), Furquim et al. (2013) and Villela et al. (2015).

\section{CONCLUSIONS}

The discussions herein, based on the relief's influences on the formation and spatialization of soils, the pedological influence on the modification of landforms and the methodological contributions from Pedology to Geomorphology regarding the evolutionary interpretation of tropical landscapes, 
indicate that the key to a full understanding of this evolution is through the integration between soils and reliefs.

Furthermore, nowadays, Pedology and Geomorphology are enriched by knowledge, techniques, and analyses from other Geosciences, especially those related to studies of geochronology. The possibility of establishing the absolute ages of soil materials is opening up a new front of action within the discipline, as it allows us to demonstrate the temporal succession of climatic, pedogenetic or morphogenetic events that have influenced the genesis and evolution of soils and landforms. The use of techniques such as Optically Stimulated Luminescence (OSL), cosmogenic isotopes or apatite fission track analysis may become the new frontier of pedological and geomorphological knowledge, as they move forward from spatial correlations and temporal inferences to an integrated analysis of time and space in the different phenomena on the earth's surface.

\section{ACKNOWLEDGMENTS}

The authors are grateful to FAPESP (São Paulo Research Foundation) for the funding of this research through Processes: 2016 / 05327-6, 2016 / 08944-6 and 2016 / 08722-3.

\section{REFERENCES}

AB'SÁBER, A. N. Conhecimento sobre as flutuações climáticas do Quaternário no Brasil. Boletim da Sociedade Brasileira de Geologia, v.6, p. 41-48, 1957.

AB'SÁBER, A. N. Revisão dos conhecimentos sobre o horizonte sub-superficial de cascalhos inhumados do Brasil Oriental. Curitiba. Boletim da Universidade do Paraná, Geografia Física, 2, 1962, p1-32.

ALMEIDA, F. F. M.; CARNEIRO, C. D. R. Origem e evolução da Serra do Mar. Revista Brasileira de Geociências, n.28, v.2, p.135-155, 1998.

ALVES, G. B.; QUEIROZ NETO, J. P; NAKASHIMA, M. R.; SILVA, J. P. As couraças e seu papel no estudo da evolução do relevo, em Maracaí/SP. Revista Geonorte, Edição Especial 4, v.10, n.1, p.34-39, 2014.

ARANHA, R. D. Estudo morfológico da bacia do Ribeirão do Baú São Bento do Sapucaí- SP. 2011. Dissertação (Mestrado em Geografia Física) - Faculdade de Filosofia, Letras e Ciências Humanas, Universidade de São Paulo, São Paulo, 2011.

BASTOS, C. A. B. Estudo geotécnico sobre a erodibilidade de solos residuais não saturados. 1999. 251f. Tese de Doutorado em Engenharia Civil apresentada a Escola de Engenharia, Universidade Federal do Rio Grande do Sul, Porto Alegre, 1999.

BENNEMA, J.; CAMARGO, M. N.; WRIGHT, A. C. S. Regional contrasts in South American soil formation in relation to soil classification and soil fertility. In: INTERNATIONAL SOIL CONFERENCE, New Zealand, Transactions, p.2-15, 1962.

BERTONI, J.; LOMBARDI NETO, F. Conservação do solo. 1. ed. Piracicaba: Livroceres, 1985. 392p.

BIGAREllA, J. J.; MARQUES FILHO, P. L.; AB'SÁBER, A. N. Ocorrência de Pedimentos Remanescentes nas Fraldas da Serra do Iquererim (Garuva, SC). Boletim Paranaense de Geografia, Curitiba, n. 4 e 5, p. 82-93, 1961.

BIGARELlA, J. J.; MOUSINHO, M.R.; SILVA, J. X. Pediplanos, pedimentos e seus depósitos no Brasil. Boletim Paranaense de Geografia, v. 16/17, p.117-151, 1965.

BOQUIER, G. Genèse et évolution de deux toposéquences de sols tropicaux du Tchad: interprétation biogéodynamique. Mém. ORSTOM, vol. 62, 1973. 351 p.

BOULET, R. Toposéquences de sols tropicaux en Haute Volta: équilibres et déséquilibres pédobioclimatiques. Mém. ORSTOM, vol. 85, 1978. 272 p. 
BOUlET, R. Análise Estrutural da Cobertura Pedológica e Cartografia. In: Anais do XXI Congresso Brasileiro de Ciência do Solo: A responsabilidade social da ciência do solo. Campinas: Sociedade Brasileira de Ciência do Solo, p. 79-90, 1988.

BOULET, R. Uma evolução recente da pedologia e suas implicações no conhecimento da gênese do relevo. In: Anais do III Congresso da Associação Brasileira de Estudos do Quaternário. Belo Horizonte: ABEQUA, 1992.

BOULET, R.; CHAUVEL, A.; HUMBEL, F. X.; LUCAS, Y. Analyse structurale et cartographie en pédologie I. Prise en compte de l'organisation bidimensionnelle de la couverture pédologique: les études de toposéquences et leurs principaux apports à la connaissance des sols. Cahiers ORSTOM, v. 19, n. 4, p. 309-322, 1982a.

BOULET, R.; CHAUVEL, A.; HUMBEL, F. X.; LUCAS, Y. Analyse structurale et cartographie en pédologie II. Une méthode d'analyse prenant en compte l'organisation tridimensionnelle des couvertures pédologiques. Cahiers ORSTOM, v. 19, n. 4, p. 323-339, 1982 b.

BOULET, R.; CHAUVEL, A.; HUMBEL, F. X.; LUCAS, Y. Analyse structurale et cartographie en pédologie III. Passage de la phase analytique à une cartographie générale synthétique. Cahiers ORSTOM, v. 19, n. 4, p. 341-351, 1982c.

BOULET, R.; CHAUVEL, R.; LUCAS, Y. Les Systèmes de Transformation en Pédologie. Libre Jubilaire du Cinquantenaire. Paris: AFES, 1984. p. 167-179.

BÜDEL, J. Climatic Geomorphology. New Jersey: Princeton University Press, 1982. 443p

CARVALHO, A.; MELFI, A.; BITTENCOURT, L; QUEIROZ NETO, J. P.; NAKASHIMA, P. Sedimentos néo-cenozóicos da área de Campinas, est. S. Paulo. In: CONGRESSO BRASILEIRO DE GEOLOGIA, 21, 1969, p. 58-70.

CASTRO, S. S. Sistemas de transformação pedológica em Marília: B latossólicos e B texturais. 1990. 274f. Tese (Doutorado em Geografia Física) - FF C H, USP, São Paulo.

CHAGAS, S. S.; FERNANDES FILHO, E. I.; BHERING, S. B. Relação entre atributos do terreno, material de origem e solos em uma área no noroeste do Estado do Rio de Janeiro. Soc. \& Nat.,

Uberlândia, v. 25, n.1, p.147-162, 2013

CHAUVEL, A. Recherches sur la transformation des sols ferrallitiques dans la zone tropicale à saisons contrastées. Mém. ORSTOM, nº. 62, 1977. 532 p.

CHAUVEL, A.; LUCAS, Y. Soil formation in tropically weathered terrains. In: GOVETT, C. J. S. (ed). Handbook if Exploration Geochemistry. NY, Elseveier., 1992, p. 57-77.

COLANGELO, A. C. O modelo de feições mínimas ou das unidades elementares de relevo: um suporte cartográfico para mapeamentos geoecológicos. Revista do Departamento de Geografia (USP), São Paulo, v. 10, p. 29-40, 1996.

COLANGELO, A. C. Geomorfossíntese e Geomorfocinemática aplicadas à evolução e estabilidade de vertentes. 2007. 228 f. Tese (Livre Docência) - Faculdade de Filosofia, Letras e Ciências Humanas, Universidade de São Paulo, São Paulo, 2007.

COLTRINARI, L. Evolução geomorfológica do Planalto de São José dos Campos (SP). 2003. 114 f. Tese (Livre Docência) - Faculdade de Filosofia, Letras e Ciências Humanas, Universidade de São Paulo, São Paulo, 2003.

COLTRINARI, L. Paleosurfaces in southeastern Brazil: São José dos Campos plateau landform evolution. Geociências, São Paulo, v. 30, n.1, p. 113-120, 2011.

COUTARD, J. P.; PEllerin, J.; AGUiAR, M. B.; COLTRINARI, L. Carta do Modelado e das Formações Superficiais do Médio Vale do Parateí - SP: Memorial Explicativo. São Paulo:

Sedimentologia e Pedologia, IGEOG-USP, n. 9, p. 1-18, 1978. Escala $1: 25.000$.

CUNHA, P.; MARQUES JÚNIOR, J.; C. N.; PEREIRA, G. T.; LEPSCH, I. F. Superfícies geomórficas e atributos de Latossolos em uma sequência areníticobasáltica da região de Jaboticabal (SP). R. Bras. 
Ci. Solo, v.29, p.81-90, 2005.

CURI, N.; FRANZMEIER, D. P. Toposequence of oxisols from the Central plateau of Brazil. Soil Sci. Soc. Am. J., v.48, p.341-346, 1984.

DELVIGNE, J. E. Pédogenèse en zone tropicale: la formation des minéraux secondaires en milieu ferralitique. Mém. ORSTOM, vol. 13, 1965. 117 p.

DEWOLF, Y. Proposition pour une définition, une typologie et une cartographie des formations superficielles. USP, Dep. Geogr., Col. Est. Cart. Form. Sup. e Aplic. Reg. Trop., vol. 1: p. 433-445, 1983.

DIAS FERREIRA, R. P.; COUTARD, J. P.; PELlERIN, J. Q.; QUEIROZ NETO, J. P. Carta Geomorfológica de São Pedro, SP (1:50.000) - Memorial Explicativo. Sedimentologia e Pedologia, São Paulo, v. 12, 1978.

DIAS FERREIRA, R. P. Solos e morfogênese em São Pedro, SP. 1997. 157. Tese (Doutorado em Geografia Física) - Dep. Geografia, FFLCH, USP, São Paulo.

DOKUCHAEV, V. V. Russian Chernozem - Volume I. Traduzido do russo por N. Kaner. Jerusalem: Israel Program for Scientific Translations, 1967. 439 p. (Selected Works of V. V. Dokuchaev)

EMPRESA BRASILEIRA DE PESQUISA AGROPECUÁRIA - EMBRAPA. Sistema brasileiro de classificação de solos. Brasília, Serviço de Produção de Informação, 1999. 412p.

ERHART, H. La Genèse des Sols en Tant que Phénomène Géologique: Esquisse d'une Théorie Géologique et Géochimique, Biostasie et Rhexistasie. Paris, Masson, 1956, 90 p.

ESPINDOLA, C. R. A pedologia e a evolução das paisagens. Revista do Instituto Geológico, Paulo, v.31, n.1/2, p.67-92, 2010.

FERNANDES BARROS, O. N. Análise estrutural e cartografia detalhada de solos em Marília/SP: ensaio metodológico. 1985. 146f. Dissertação (Mestrado em Geografia Física) - Dep. Geografia, FFLCH, USP, São Paulo.

FEUER, R. An Exploratory Investigation of the Soils and Agricultural Potential of the Soils of the Future Federal District in the Central Plateau of Brazil. Cornell University, 1956, 864 p.

FURQUIM, S. A. C. Interações Entre Modelado e Solo no Transecto Espraiado, São Pedro, SP. 2002. 170 f. Dissertação (Mestrado) - Faculdade de Filosofia, Letras e Ciências Humanas, Universidade de São Paulo, São Paulo, 2002.

FURQUIM, S. A. C.; COLTRINARI, L.; DIAS FERREIRA, R. P.; CASTRO, S. S.; PUGLIESE, G. R. Lamellae Formation Processes in Tropical Soils in Southeastern Brazil. Catena (Cremlingen), v. 107, 2013, p. 15-25.

GALETI, P. A. Conservação do solo, reflorestamento, clima. 2. ed. Campinas: Instituto Campineiro de Ensino Agrícola, 1982. 286p.

GALLANT, J. C.; WILSON, J. P. Primary topographic attributes. In: WILSON, J. P.; GALLANT, J. C. (Eds.). Terrain Analysis: Principles and applications. New York: John Wiley \& Sons, 2000. p.51-85.

GALVÃO, S. R. S.; SALCEDO, I. H.; SANTOS, A. C. Frações de carbono e nitrogênio em função da textura, do relevo e do uso do solo na microbacia do agreste em Vaca Brava (PB). R. Bras. Ci. Solo, v.29, n.4, p.955-962, 2005.

GROSSMAN, R. B. Entisols. In: WILDING, L. P.; SMECK, N. E.; HALL, G. F. (Eds.). Pedogenesis and soil taxonomy. II. The soil orders. Developments in soil science. New York: Elsevier, 1983. v.11b, p.55-86.

HALL, G. F.; OLSON, C. G. Predicting variability of soils from landscape models. In: MAUSBACH, M. J.; WILDING, L. P. (Eds.). Spatial variabilities of soils and landforms. Madison, Wisconsin: Soil Science Society of America, 1991. p. 9-24. (SSSA Special Publication; nº 28).

JENNY, H. Factors of soil formation. 1.ed. New York, McGraw- Hill, 1941. 362p. 
JOURNAUX, A. O Estudo das Formações Superficiais na França. Sedimentologia e Pedologia, n. 4, Instituto de Geografia, Universidade de São Paulo, São Paulo, 1973, p. 1-19.

LACERDA, M. P. C.; BARBOSA, I. O.; MENESES, P. R.; ROSA, J. W. C.; ROIG, H. L. Aplicação de geotecnologias em correlações entre solos, geomorfologia, geologia e vegetação nativa no Distrito Federal, DF. In: SIMPÓSIO BRASILEIRO DE SENSORIAMENTO REMOTO, 12., Goiânia, 2005. Anais. Goiânia, INPE, 2005. p.2211-2218. CD-ROM.

LEÃO, M. G. A. 119f. Relação entre atributos de uma vertente com Latossolos e qualidade de frutos cítricos. Dissertação (Mestrado em Ciência do Solo), Faculdade de Ciências Agrárias e Veterinárias, Universidade Estadual Paulista, Jaboticabal, 2004.

LEPSCH, I. F.; BELLINAZZI JR., R.; BERTOLINI, D.; ESPÍNDOLA, C. R. Manual para levantamento utilitário do meio físico e classificação de terras no sistema de capacidade de uso. $4^{\mathrm{a}}$ aproximação. Campinas: SBCS, 1991, 175p

LEPSCH, I. F.; BUOL, S. W. Oxisol Landscape relationships in Brazil. In: INTERNATIONAL SOIL CLASSIFICATION WORKSHOP, 13., Campinas, 1986. Papers. Campinas, SNLCS/Embrapa, USDA, University of Puerto Rico, 1986. p.174-189.

LUCAS, Y.; CHAUVEL, A.; BOULET, R.; RANZANI, G.; SCATOLINI, F. Transição latossolos podzóis sobre Formação Barreiras na região de Manaus. Rev. Bras. Ci. Solo, v. 8, p. 325- 335, 1984.

MILLOT, G. Géochimie de la surface et formes du relief - présentation. Sci. Géol. Bull., Strasbourg, v. 30, n. 4, 1977, p. 229-233.

MILLOT, G. Planation of Continents by Intertropical Weathering and Pedogenetic Processes. In: International Seminar on Lateritisation Processes, 1983, São Paulo. Proceedings... São Paulo: IUGS, UNESCO, IGCP, IAGC, 1983. p. 53-63.

MILNE, G. Some suggested units of classification and mapping particularly for East African soils. Soil Research, v. n.3, p. 183-198, 1935.

MILNE, G. Normal erosion as a factor in soil profile development. Nature, set., 26, p. 548-549, 1936.

NAKASHIMA, M. R.; ALVES, G. B.; BARREIROS, A. M.; QUEIROZ NETO, J. P. Dos solos à paisagem: uma discussão teórico-metodológica. Revista da ANPEGE, v. 13, p. 30-52, 2017.

OLIVEIRA, J. B.; JACOMINE, P. K. T.; CAMARGO, M. N. Classes Gerais de Solos do Brasil. Jaboticabal, FUNEP, 1992. 201p.

PELLERIN, J.; HELLUIN, M. Análise estrutural e organização das paisagens: as pesquisas visando a generalização cartográfica. In: CONGRESSO BRASILEIRO DE CIÊNCIA DO SOLO, 21, 1998, Campinas. Anais, Sociedade Brasileira de Ciência do Solo, p. 455-463, 1988.

PENTEADO, M. M. Fundamentos de Geomorfologia. $2^{\text {a }}$ ed., Rio de Janeiro: IBGE, 1978, 180p.

QUEIROZ NETO, J. P. Interpretação dos solos da Serra de Santana para fins de classificação. USP, ESALQ, Tese de Doutoramento, 1969, 123 p.

QUEIROZ NETO, J. P. O Estudo das Formações Superficiais no Brasil. Revista do Instituto Geológico 22 (1/2), São Paulo, 2001, p. 65-78.

QUEIROZ NETO, J. P. Análise Estrutural da Cobertura Pedológica: Uma Experiência de Ensino e Pesquisa. Revista do Departamento de Geografia, $\mathrm{n}^{\circ}$ 15, pp. 77 - 90, 2002.

QUEIROZ NETO, J. P. O papel da pedogênese no modelado do relevo: busca de novos paradigmas. In: SEMINÁRIO LATINO AMERICANO DE GEOGRAFIA FÍSICA, 6 E SEMINÁRIO IBERO AMERICANO DE GEOGRAFIA FÍSICA, 2, 2010, Coimbra. Anais, Coimbra, 2010, p.1-19.

QUEIROZ NETO, J. P. Relações entre as vertentes e os solos: revisão de conceitos. Revista Brasileira de Geomorfologia, v. 12, n.3, p. 15-24, 2011.

RESENDE, M.; CURI, N.; KER, J. C.; REZENDE, S. B. Mineralogia de solos brasileiros: Interpretação e aplicações. Lavras, Universidade Federal de Lavras, 2005.192p. 
ROSS, J. S. Registro cartográfico dos fatos geomorfológicos e a questão da taxonomia do relevo.

Revista do Departamento de Geografia (USP), v.6, p.17-29, 1992.

RUBIRA, F. G.; MELO, G. V.; OLIVEIRA, F. K. S. Proposta de padronização dos conceitos de erosão em ambientes úmidos de encosta. Revista de Geografia (Recife), v.33, n.1, p.168-193, 2016.

RUBIRA, F. G.; PEREZ FILHO, A.; MELO, G. V. Análise macromorfológica da cobertura pedológica e perfil da topossequência realizada em um segmento da vertente da FEI/UEM. In: SIMPÓSIO BRASILEIRO DE GEOGRAFIA FÍSICA APLICADA E CONGRESSO NACIONAL DE GEOGRAFIA FÍSICA, 17/1, 2017, Campinas - SP. Anais, v.1, p.1-13, 2017.

RUELLAN, A. Contribuição das pesquisas em Zona Tropical ao desenvolvimento da Ciência do Solo. In: CONGRESSO BRASILEIRO DE CIÊNCIA DO SOLO, 21, 1998, Campinas. Anais, Sociedade Brasileira de Ciência do Solo, p. 405-414, 1988.

RUELLAN, A.; DOSSO, M. Regards sur le sol. Paris: Éditions Foucher-AUPELF, Collection Universités francophones, 1993. 192 p.

RUHE, R. V. Geomorphology: geomorphic processes and surficial geology. Boston, Massachusetts: Houghton Mifflin, 1975, 246 p.

SANTOS, A. C. Fertilidade do solo e redistribuição de ${ }^{137} \mathrm{Cs}$ em função da cobertura vegetal, relevo e classes texturais, em uma microbacia hidrográfica do Estado da Paraíba. 67f. Tese (Doutorado em Tecnologias nucleares e energéticas). Centro de Tecnologias e Geociências, Universidade Federal de Pernambuco, 2004.

SANTOS, A. C.; SALCEDO, I. H.; CANDEIAS, A. L. B. Relação entre o relevo e as classes texturais do solo na microbacia hidrográfica de Vaca Brava, PB. Revista Brasileira de Cartografia, $\mathrm{n}^{\circ} \quad$ 54, p.86-94, 2002.

SANTOS, A. C.; SALCEDO, I. H.; GALVÃO, S. R. S. Relações entre uso do solo, relevo e fertilidade do solo em escala de microbacia. Revista Brasileira de Engenharia Agrícola e Ambiental v.12, n.5, p.458-464, 2008.

SILVA, A. C.; TORRADO, P. V. Gênese dos Latossolos húmicos e sua relação com a evolução da paisagem numa área cratônica do Sul de Minas Gerais. R. Bras. Ci. Solo, v.23, p.329-341, 1999.

SILVA, A. C.; TORRADO, P. V.; PÉREZ, M. G.; MARTIN NETO, L.; VASQUEZ, F. M. Relações entre matéria orgânica do solo e declividade de vertentes em topossequência de Latossolos do sul de Minas Gerais. R. Bras. Ci. Solo, v.31, p.1059-1068, 2007.

SILVEIRA, C. T.; FIORI, A. P.; FERREIRA, A. M.; FELIPE, R. S.; KEPEL FILHO, J. L.; FOLADOR, R. M.; COSTA, L. C. Análise do fator de segurança da estabilidade das vertentes na bacia do rio Jacareí, serra do mar paranaense. Revista Brasileira de Geomorfologia, v.13, n.3, p.287-297, 2012.

SOUZA JUNIOR, J. G. A.; DEMATTÊ, J. A. M. Modelo digital de elevação na caracterização de solos desenvolvidos de basalto e material arenítico. R. Bras. Ci. Solo, n.32, p. 449-456, 2008.

SOUZA, C. K.; MARQUES JUNIOR, J.; MARTINS FILHO, M. V.; G. T. PEREIRA. Influência do relevo e erosão na variabilidade espacial de um Latossolo em Jaboticabal (SP). R. Bras. Ci. Solo, n.27, p.1067-1074, 2003.

SOUZA, Z.; MARQUES JÚNIOR, J.; PEREIRA, G. T. Variabilidade espacial de atributos físicos do solo em diferentes formas do relevo sob cultivo de cana-de-açúcar. R. Bras. Ci. Solo, v.28, p.937-944, 2004.

THOMAS, M. F. Geomorphology in the Tropics: A Study of Weathering and Denudation in Low Latitudes. Chichester: Wiley, 1994. 460 p.

TRICART, J. Tentative de corrélation des périodes pluviales africaines et des périodes glaciaires. C. R. Somm des Séances Soe. Geol. de France, Paris, n.9, p. 164-167, 1956.

TRICART, J. Observation des Phénomènes et des Faits Géomorphologiques. In: TRICART, J. La Cartographie Géomorphologique Détaillée. Principes et Méthodes de la Géomorphologie. Paris: 
Masson e Cie Editeurs, 1965. p. 183-233.

TRICART, J. As relações entre a morfogênese e a pedogênese. Notícia Geomorfológica, v. 8, n. 15, p. $5-18,1968$.

TRICART, J.; CAILLEUX, A. Morphoclimatic Mechanisms. In: TRICART, J.; CAILLEUX, A. Introduction to Climatic Geomorphology. Longman, 1972, p. 47-65.

TROEH, F. R. Landform equations fitted to contour maps. American Journal of Science, v.263, p. 616 - 627, 1965.

VILLELA, F. N. J.; ROSS, J. L. S.; MANFREDINI, S. Análise Geomorfopedológica na Borda Leste da Bacia Sedimentar do Paraná, Sudeste do Brasil. Revista Brasileira de Geomorfologia, v. 16, 2015, p. 669-682.

YOUNG, A. Slopes. Edinburgh: Oliver and Boyd, 1972, 288p. 